\title{
Determination of Arsenic in Minor Cereals (Barley, Foxtail Millet, Proso-Millet, Finger- Millet, Pearl -Millet, Buckwheat, Oat, Quinoa and Sorghum) in Gazipur, Bangladesh
}

\author{
Shanaj Parvin ${ }^{1,3 *}$, Md Ehsanul Haque ${ }^{2}$, Fahmida Akhter ${ }^{1}$, Mubarak Ali ${ }^{1}$ and Most Shaikha Shafin ${ }^{1}$ \\ ${ }^{1}$ Bangladesh Agricultural Research Institute, Joydebpur, Gazipur, Bangladesh \\ ${ }^{2}$ University of North Dakota, Grand Forks, USA \\ ${ }^{3}$ Faculty of Natural Science, Leibniz University Hannover, Germany
}

*Corresponding author: Shanaj Parvin, Bangladesh Agricultural Research Institute, Joydebpur, Gazipur, Bangladesh, Faculty of Natural Science, Leibniz University Hannover, Germany

\section{ARTICLE INFO}

Received: 㓞 November 26, 2021

Published: 絊 December 08, 2021

Citation: Shanaj Parvin, Md Ehsanul Haque, Fahmida Akhter, Mubarak Ali. Determination of Arsenic in Minor Cereals (Barley, Foxtail Millet, Proso-Millet, Finger- Millet, Pearl -Millet, Buckwheat, Oat, Quinoa and Sorghum) in Gazipur, Bangladesh. Biomed J Sci \& Tech Res 40(3)2021. BJSTR. MS.ID.006449.

\section{ABSTRACT}

Cereal grains are the most important source of the world's total food and also the major accumulator of toxic arsenic. Arsenic distributes in the environment via contaminated ground water which is used as drinking water and irrigated in the crop field. Chronic arsenic toxicity can be lethal for liver, kidney, bladder, lung, skin. Skin hyperpigmentation and hyperkeratosis are common exposure related phenotypes. Therefore, it's high time to produce ideal cereals that must contain a lower amount of arsenic and ensure safety for all kinds of lives. Ensuring safe food is one of the objectives of sustainable development goal-2 (SDG-2). With this view in mind, the Plant Breeding Division of BARI currently working with nine minor kinds of cereal included Barley, Foxtail millet, Proso-millet, Finger-millet, Pearl-millet, Buckwheat, Oat, Quinoa, and BARI-Sorghum 1 were undertaken for biochemical analysis of arsenic on their leaves. The biochemical analysis of these nine kinds of minor cereals showed negligible amount of arsenic on leaves. Further analysis in other location in Bangladesh might bring the overall picture of arsenic uptake in minor cereals.

\section{Introduction}

Cereals are a staple food for many people around the world including Bangladesh; however, they are also a major dietary source of toxic arsenic (As). Most agricultural lands of Bangladesh are contaminated with arsenic (59 out of 64 districts are arsenic contaminated according to IAEA [1] which can be accumulated to high levels in the grains of cereals cultivated in these regions, posing serious health risks to consumers. Arsenic has two forms such as trivalent (ASIII) and pentavalent (AsV), thus it has larger atomic radius, more electron clouds, relative higher reaction affinity (ASIII) to thiol group/sulfhydryl group (-SH) groups than other divalent cations Most and Papenbrock [2]. As such this notorious heavy metal being efficiently absorbed in skin, lung, kidney, liver, and bladder than any other heavy metals. Though, the level of arsenic contamination and its consequence has been well studied in rice, however, a similar study has not been performed in other cereals (like wheat, maize, barley, and foxtail millet, etc.) despite their increasing trend of production and end-use. Hence, to save the nation, it is imperative to develop cereals that will contain reduced levels of arsenic. Genetic engineering strategies could be 
employed to develop a variety that will retain a lower amount of toxic arsenic. Therefore, the level of arsenic in the existing cereals has to be determined as a starting point towards lower arsenic variety development. Thus, the arsenic content in the minor cereals available in PBD and grown in Joydebpur soil (Barley, Foxtail millet, Proso-millet, Finger-millet, Pearl-millet, Buckwheat, Oat, Quinoa, and BARI-Sorghum 1) were determined in this experiment. The primary arsenic status of these cereals may have given clues for designing the appropriate breeding program in the future.

\section{Materials and Methods}

The leaves of available nine kinds minor of cereal (Barley, Foxtail millet, Proso-millet, Finger- millet, Pearl-millet, Buckwheat, Oat, Quinoa, and BARI-Sorghum 1) were collected from Joydebpur experimental field to their total arsenic accumulation. Before elemental analysis, the leaves samples were oven-dried at a constant temperature of $65^{\circ} \mathrm{C}$ for 10 days. Subsequently, dried leaves were grounded into fine powder for arsenic level determination. Simultaneously, a soil sample from the same location was collected and subjected to arsenic level determination. The elemental analysis was performed by the soil science division of BARI.

\section{Results and Discussion}

The chemical analysis of nine kinds of cereal has shown arsenic accumulation in their leaves in (Table 1). The unit value of arsenic was expressed in ppm ( $\mathrm{mg} \mathrm{l}^{-1}$ or $\left.\mathrm{mg} \mathrm{kg}^{-1}\right)$. The table depicted that total arsenic accumulation of all the minor cereals was remaining an acceptable limit (1-920 $\mathrm{g} \mathrm{kg}^{-1}$ ). The acceptable limit of arsenic in the terrestrial plant was determined less than $10 \mathrm{mg} \mathrm{kg}^{-1}$ under normal conditions (Matschullat, 2000). Several plants contain arsenic in the following order: cabbage $\left(0.020-0.050 \mathrm{mg} \mathrm{kg}^{-1}\right)<$ carrots $(0.040-0.080)<$ grass $(0.020-0.160)<$ potatoes $(0.020$ $0.200)<$ lettuce $(0.020-0.250)<$ mosses and lichens $(0.26)<$ ferns (1.3) Matschullat [3]. Comparing the arsenic content in the abovementioned crops with the nine minor kinds of cereal of PBD, all the cereals have shown a negligible amount of arsenic. Although it has been shown that BARI Kaon-1 contains an increasing amount of arsenic comparing with others, it holds arsenic an acceptable limit; because, an average toxicity threshold of $40 \mathrm{mg} \mathrm{kg}^{-1}$ was established for crop plants Sheppard [4]. The soil-arsenic analysis was shown $3 \mathrm{mg} \mathrm{kg}^{-1}$ which is also negligible that indicates corresponding sites are not contaminated by arsenic. According to Adriano [5], soilarsenic concentration typically varies from below $10 \mathrm{mg} \mathrm{kg}^{-1}$ in noncontaminated soils to as high as $30,000 \mathrm{mg} \mathrm{kg}^{-1}$ in contaminated soils Vaughan [6]. So, it is pragmatic when the soil has less amount of arsenic and crop grown in that particular soil must have less amount of arsenic. In the current experimental condition, it is not possible to say that the crops have less capacity for arsenic accumulation. It could possible they can extract higher arsenic in contaminated soil.

Table 1: Total arsenic analysis of nine kinds of minor cereal and one soil sample.

\begin{tabular}{|c|c|c|c|}
\hline & $\begin{array}{c}\text { Name of the } \\
\text { samples }\end{array}$ & Arsenic (ppm) & $\begin{array}{c}\text { Arsenic } \mathbf{~ m g ~ k g}^{-1} \text { or } \\
\mathbf{~ m g ~ l} \mathbf{~ l}^{-1} \text { ) }\end{array}$ \\
\hline 1 & Cheena & 0.001 & 0.00099 \\
\hline 2 & Pearl-millet & 0.001 & 0.00099 \\
\hline 3 & BARI-Sorghum 1 & 0.001 & 0.00099 \\
\hline 4 & Quinoa & 0.001 & 0.00099 \\
\hline 5 & BARI Barley-4 & 0.001 & 0.00099 \\
\hline 6 & Oats & 0.001 & 0.00099 \\
\hline 7 & Buckwheat & 0.01 & 0.00998 \\
\hline 8 & Finger millet & .014 & 0.01398 \\
\hline 9 & BARI-Kaon-1 & 0.92 & 0.97888 \\
\hline 10 & Soil & 3.1 & 3.09646 \\
\hline
\end{tabular}

\section{Conclusion}

The cereals grown in Joydeppur's experimental field have shown non-contamination by arsenic. Therefore, it can be said that seeds produced in Joydebpur experimental field and distributed to farmers and other organizations are free of arsenic. Safe food consumption is not only significant for human but also require for other animals, therefore, ensuring safe food for all kind of lives is one of the objectives of sustainable development goal-2 (SDG2). The biochemical analysis needs to be extended for crops that are growing in arsenic-contaminated sites, typically Chandpur, Munshiganj, Gopalganj, Madaripur, Noakhali, Satkhira, Comilla, Meherpur, Bagerhat and Khulna region which are the high arseniccontaminated zone. In addition, similar analysis can be carried out in control conditions where crops will be subjected to varying concentrations of arsenic. The expected output could help to developing an arsenic resistance crop.

\section{References}

1. (2002) IAEA. Arsenic contamination of groundwater in Bangladesh, International Atomic Energy Agency, Vienna.

2. Most P, Papenbrock J (2015) Possible Roles of Plant Sulfurtransferases in Detoxification of Cyanide, Reactive Oxygen Species, Selected Heavy Metals and Arsenate. Molecules 20(1): 1410-1423.

3. Matschullat J (2000) Arsenic in the geosphere-a review. Science of the Total Environment 249(1-3): 297-312.

4. Sheppard BS, Caruso JA, Heitkemper DT, Wolnik KA (1992) Arsenic speciation by ion chroma- tography with inducedcoupled plasma mass spectrometry detection. Analyst 117(6): 971- 975.

5. Adriano DC (1986) Trace elements in the terrestrial environment. Springer, pp. 867.

6. Vaughan GT (1993) The environmental chemistry and fate of arsenical pesticides in cattle tick dip sites and banana land plantations. Melboune: CSIRO Division of Coal Industry, Center for Advanced Analytical Chemistry, NSW. 
ISSN: 2574-1241

DOI: 10.26717/BJSTR.2021.40.006449

Shanaj Parvin. Biomed J Sci \& Tech Res

CC (i) This work is licensed under Creative

Submission Link: https://biomedres.us/submit-manuscript.php

$\begin{array}{ll}\text { BIOMEDICAL } & \text { Assets of Publishing with us } \\ \text { RESEARCHES } & \text { - Global archiving of articles } \\ \text { - Immediate, unrestricted online access } & \text { - Rigorous Peer Review Process } \\ & \text { - Authors Retain Copyrights } \\ \end{array}$

